\title{
Soil nutrients, microbial biomass, and crop response to organic amendments in rice cropping system in the Shiwaliks of Indian Himalayas
}

\author{
Richa Rajput $^{1} \cdot$ Priya Pokhriya $^{1} \cdot$ Pooja Panwar $^{1} \cdot$ A. Arunachalam ${ }^{2} \cdot$ Kusum Arunachalam $^{1}$ (i)
}

Received: 1 May 2018 / Accepted: 1 November 2018 / Published online: 11 November 2018

(c) The Author(s) 2018

\begin{abstract}
Purpose Intensive agriculture activities in small holder farming systems are declining over all soil nutrient status. The present study is conducted to compare the soil health and plant growth attributes under rice cultivation among different organic amendments. Recycled waste of rice-wheat agrosystem is utilized to determine optimal sustainable solution for hilly areas. Methods Randomly blocked design experiment was conducted with rice plants, each amended with organic inputs including rice straw residue (T1), rice biochar (T2), rice compost (T3), wheat straw residue (T4), wheat biochar (T5), wheat compost (T6), mix of wheat + rice compost (T7), green manure (T8) and control (no amendment). Soil samples were studied at each growth phase while plant growth attributes were measured at the harvesting stage of the crop.

Results T6 and T7 have shown significantly higher magnitude of soil organic carbon, microbial biomass carbon, microbial quotient, available nitrogen, and enzymatic activities (dehydrogenase, alkaline phosphatase and urease) than biochar (T2 and T5) and crop residue amendments (T1, T4 and T8). An increase of up to 47\% was obtained in cumulative growth attributes (plant height, total biomass, and a number of tillers, spikes, and spike length) of rice plant in T6 amendment. The principal component analysis revealed two components responsible for $54.17 \%$ of the variance in the organically treated soil.

Conclusion The experimental results imply that composting of crop residues could be the most reliable practice to improve soil nutritional quality as well as crop growth for sustainable rice-wheat cropping system in the hilly area.
\end{abstract}

Keywords Crop residue $\cdot$ Compost $\cdot$ Biochar $\cdot$ Microbial biomass $\cdot$ Soil enzymes $\cdot$ Rice crop

\section{Introduction}

Sustainable agriculture envisages efficient utilization of agricultural waste in a way that it does not deplete the existing nutritious entities of the soil and replenish it in the long run. The overuse of chemical fertilizers and gapless recurring farming activities reportedly deteriorates soil (Komatsuzaki and Ohta 2007). For instance, nutrition cycle of the soil gets impaired due to the presence of readily available nutrients in the form of fertilizers which hampers the natural unidirectional flow of immobilisation and mineralization of natural elements of the soil which in turn affects the growth of the living components of the soil, i.e., microorganisms (Heilmann et al. 1995; Kuzyakov et al. 2000; Harris and Roach 2018). This has led to the eco-friendly option of organic farming that fulfills the requirement of both sustainable agriculture and conservation agriculture, where the output of one activity transforms into the input for other. Various innovative approaches have been investigated for 
the suitability of organic wastes as soil fertility enhancer. Pampuro et al. (2017) studied the potential of pig slurry solid fraction pellets as fertilizer in maize crop whereas Joardar and Rahman (2018) utilized poultry feather waste as compost to analyze its effect on the vegetable test crop Ipomoea aquatica. The availability of surplus agriculture waste from rice-wheat agro-ecosystem makes it a suitable potential model for sustainable agriculture. Both rice and wheat cropping systems demand labor-intensive farming practices, where a required level of nutrition has to be maintained in the soil for the crop productivity. Due to small land holdings of farmers from hilly states, agriculture intensification is carried out by open burning of crop residues for field clearing and supplementation with inorganic fertilizers to meet the nutritional demands of the soil which have its environmental consequences such as polluted run offs, soil erosion and release of harmful gases. Reuse of organic waste through composting is promoted as a primary measure to mitigate such environmental threats by developed nations (Pampuro et al. 2016). The government of India has also resolved to promote these states to adopt more environmentally friendly approach through organic farming where organic wastes such as crop residue, composted residues, and biochar could become means for enhancing soil quality as well as crop productivity. Himalayan areas have always been embraced as horticulture belts because of the presence of optimum microclimatic conditions for the same (Partap 2011). But due to ever increasing demand for global food production measures are being taken to promote more cereal farming activities in these areas. Most successful stories of organic farming have been known in the field of vegetables and fruit crops, but the very limited emphasis has been laid on developing these small land holdings into intense cereal cropping systems. The same can be achieved by organic farming due to its default presence in the area and willingness of small farmers to adapt because of less production cost. Organic farming, although it has been a traditional practice in the hills, is a way forward to maintain the health and fertility of the soil.

Various previous studies have reported that diverse organic farming practices applied in cereal crops have resulted in improved soil condition and enhanced crop yield particularly in hilly terrains (Roy et al. 2010; Kumar Choudhary and Suri 2014; Paudel et al. 2014; Pampuro et al. 2017). Even different organic forms of compost impart distinct soil quality characteristics based on either particle size or composting methods adopted, such as reported by authors in compost prepared from pig slurry incorporated with saw dust, wood chips, and wheat straw (Romano et al. 2014; Pampuro et al. 2016). Crop residue retention along with conventional tillage proved to be a promising option to reduce nutrient loss in the study of Murphy et al. (2016) in small holder maize system. A study in the lines with similar objective of the present investigation compared dairy manure with hardwood biochar and outlined contrasting results on microbial communities and enzyme activities of the soil (Elzobair et al. 2016). Nonetheless, some authors have also reported negative results of the application of organic amendments into the soil (Elliott et al. 1978; Putnam 1994). Global climate change is affecting the Himalayan ecosystem the most, causing monsoon deficiency, desertification, and soil degradation in hilly farmlands, hence leading to stagnant crop growth. Therefore, it is imperative to study overall soil quality parameters corresponding to each organic amendment before zeroing upon effective nutrient management practice for a specific cropping system under stress conditions. Several authors have studied changes in microbial composition, enzymatic activities, and soil respiration as a parameter to determine the biological state of the soil (Chang et al. 2014; Zhen et al. 2014; Yu et al. 2016). Based on the exclusive nutritional requirements of both the rice and wheat cropping systems, each and every known organic amendment input must be studied and analyzed before its application into the fields, as every terrain and agriculture farm is different in terms of its distinct abiotic and biotic factors. In the present study, various indigenously known organic inputs from preceding crop and current crop have been applied to the soil under rice cultivation system to understand the comparative advantages it confers to the soil. The amended soils are tested on the criteria of physicochemical and biological parameters to determine the best suited organic amendment for the soil that manifests enhanced crop productivity.

\section{Materials and methods}

\section{Study site and experimental setup}

The experiment was conducted at Doon University farm, Dehradun, India $\left(30.2672^{\circ} \mathrm{N}, 78.0465^{\circ} \mathrm{E}\right)$ located at an elevation of $637 \mathrm{~m}$ asl, with an annual rainfall of $2070 \mathrm{~mm}$, and average maximum and minimum temperature is 30.4 and $16.7^{\circ} \mathrm{C}$, respectively. Across the years, July and August are the wettest months.

Bulk soil from the rice-wheat system was brought from the field for utility in the pot experiments. The soils were sandy loam with a bulk density of $1.4 \mathrm{Mg} \mathrm{m}^{-3}$, slight alkaline with the electrical conductivity of $1.6 \mathrm{dS} \mathrm{m}^{-1}$ and rich in soil organic carbon (SOC), available $\mathrm{P}$ and $\mathrm{K}$, and low in available $\mathrm{N}$ (Table 1).

For the present experiment, organic inputs chosen were mainly applied in three forms, i.e., leftover crop residue, compost, and biochar. The experiment was conducted in pots of $30 \times 31 \mathrm{~cm}$, filled with nearly $25 \mathrm{~kg}$ of field moist soil, collected from top 0-30 cm soil layer and kept under ambient conditions. Total nine treatments including control pot (no amendment) were used in triplicates. Organic inputs 
Table 1 Physico-chemical properties of field soil rice-wheat system

\begin{tabular}{lc}
\hline Physicochemical properties & Values \\
\hline Bulk density $\left(\mathrm{Mg} / \mathrm{m}^{3}\right)$ & 1.4 \\
$\mathrm{pH}$ & 7.5 \\
Electrical conductivity $\left(\mathrm{dSm}^{-1}\right)$ & 1.6 \\
Soil organic carbon & 1.23 \\
Available $\mathrm{N}\left(\mathrm{mg} \mathrm{kg}^{-1}\right)$ & 16.49 \\
Available $\mathrm{P}\left(\mathrm{mg} \mathrm{kg}^{-1}\right)$ & 8.28 \\
Available K $\left(\mathrm{mg} \mathrm{kg}^{-1}\right)$ & 30.9 \\
Total $\mathrm{Mg}\left(\mathrm{mg} \mathrm{kg}^{-1}\right)$ & 63.34 \\
Total Cu $\left(\mathrm{mg} \mathrm{kg}^{-1}\right)$ & 0.748 \\
Total $\mathrm{Fe}\left(\mathrm{mg} \mathrm{kg}^{-1}\right)$ & 130.73 \\
Total $\mathrm{Zn}\left(\mathrm{mg} \mathrm{kg}^{-1}\right)$ & 3.636 \\
Total $\mathrm{Pb}\left(\mathrm{mg} \mathrm{kg}^{-1}\right)$ & 0.713 \\
\hline
\end{tabular}

were incorporated at a rate of $2.5 \mathrm{t} \mathrm{ha}^{-1}$ into the soil, only once before sowing the rice crop. No other form of fertilizer was applied to the experimental pots to provide any additional nutrient. After 15 days of preparation of pots, 21-dayold rice seedlings were planted in July 2016, which were thinned to five plants in a pot. Pots were watered whenever required and were maintained weed free manually. Triplicate soil samples, from each experimental pot, were collected from a depth of $0-10 \mathrm{~cm}$ at four different stages of crop growth from July (sowing) till Oct 2016 (harvesting). The soil samples were air dried, crushed, and sieved through a $2 \mathrm{~mm}$ mesh and packed in sealed plastic bags. Soil samples were kept at $4{ }^{\circ} \mathrm{C}$ for further analysis. Plant growth parameters were studied after 16 weeks of fertilization treatments.
The destructive sampling method was followed to estimate total plant height, number of tillers and spike length. The collected samples were oven dried at $80{ }^{\circ} \mathrm{C}$ for $48 \mathrm{~h}$ to measure dry weight.

Crop residues of wheat, rice and, green manure were mixed up to $5 \mathrm{~cm}$ depth in the soil after cutting it into pieces of approximately $1 \mathrm{~cm}$. Compost was prepared aerobically in a composter with holes for the aeration. Straws of rice and wheat cut into pieces of nearly $1 \mathrm{~cm}$ were used. Compost was prepared by placing raw material in a layered manner by adding layers of straw and green grass clippings and leaves, to maintain requisite amount of carbon and nitrogen ratio in the compost. Moisture was maintained throughout the making of compost by sprinkling adequate amount of water and the compost was overturned periodically to keep the flow of air into the pile. Samples were taken for chemical analysis after 90 days in case of wheat compost and 120 days in rice compost when the temperature was dropped down from $60{ }^{\circ} \mathrm{C}$ to about $35{ }^{\circ} \mathrm{C}$ and moisture was detected at $55 \%$ (Table 2).

Biochar was prepared in a charring kiln provided by Samuchit envirotech, a social enterprise based in Pune. The dried organic waste was filled up to the brim, then covered and flash burnt. The char was used after no more flames were coming out from the equipment and it was cold. The samples were collected immediately for chemical analysis.

\section{Soil properties}

Soil available $\mathrm{N}$ was extracted with $\mathrm{KMnO}_{4}$; ammonium borate formed in the process was titrated with $0.02 \mathrm{~N} \mathrm{H}_{2} \mathrm{SO}_{4}$

Table 2 Chemical composition of organic treatments

\begin{tabular}{|c|c|c|c|c|c|c|c|c|}
\hline $\begin{array}{l}\text { Chemical compo- } \\
\text { sition }\end{array}$ & $\begin{array}{l}\mathrm{T} 1 \\
\text { Rice residue }\end{array}$ & $\begin{array}{l}\mathrm{T} 2 \\
\text { Rice biochar }\end{array}$ & $\begin{array}{l}\text { T3 } \\
\text { Rice compost }\end{array}$ & $\begin{array}{l}\text { T4 } \\
\text { Wheat residue }\end{array}$ & $\begin{array}{l}\text { T5 } \\
\text { Wheat biochar }\end{array}$ & $\begin{array}{l}\text { T6 } \\
\text { Wheat compost }\end{array}$ & $\begin{array}{l}\mathrm{T} 7 \\
\text { Wheat + rice } \\
\text { compost }\end{array}$ & $\begin{array}{l}\mathrm{T} 8 \\
\text { Green manure }\end{array}$ \\
\hline $\mathrm{pH}$ & 6.9 & 9.5 & 7.5 & 7.1 & 9.7 & 7.3 & 7.5 & 7.2 \\
\hline $\mathrm{EC}\left(\mathrm{dSm}^{-1}\right)$ & 1.6 & 0.71 & 2.3 & 1.8 & 0.76 & 2.1 & 2.2 & 1.5 \\
\hline SOC $\%$ & 1.8 & 1.5 & 2.1 & 2.7 & 1.8 & 3.4 & 3.6 & 1.2 \\
\hline $\begin{array}{r}\text { Available N } \\
\left(\mathrm{mg} \mathrm{kg}^{-1}\right)\end{array}$ & 7.31 & 18.30 & 29.44 & 12.31 & 21.34 & 26.70 & 33.66 & 35.70 \\
\hline $\begin{array}{r}\text { Available P } \\
\left(\mathrm{mg} \mathrm{kg}^{-1}\right)\end{array}$ & 7.20 & 3.83 & 15.62 & 8.40 & 4.73 & 15.61 & 17.70 & 2.13 \\
\hline $\begin{array}{l}\text { Available K } \\
\quad\left(\mathrm{mg} \mathrm{kg}^{-1}\right)\end{array}$ & 12.11 & 18.40 & 33.42 & 13.81 & 22.10 & 42.64 & 33.56 & 12.32 \\
\hline $\begin{array}{l}\text { Total } \mathrm{Mg}^{-1} \\
\quad\left(\mathrm{mg} \mathrm{kg}^{-1}\right)\end{array}$ & 28.23 & 36.20 & 82.04 & 30.56 & 50.31 & 69.82 & 72.52 & 22.10 \\
\hline $\begin{array}{l}\text { Total Cu } \\
\quad\left(\mathrm{mg} \mathrm{kg}^{-1}\right)\end{array}$ & 0.34 & 0.38 & 0.9 & 0.52 & 0.30 & 0.6 & 0.75 & 0.23 \\
\hline Total Fe $\left(\mathrm{mg} \mathrm{kg}^{-1}\right)$ & 86.32 & 77.64 & 131.24 & 90.45 & 128.70 & 126.28 & 125.76 & 32.23 \\
\hline $\begin{array}{l}\text { Total Zn } \\
\quad\left(\mathrm{mg} \mathrm{kg}^{-1}\right)\end{array}$ & 1.25 & 1.68 & 3.48 & 2.45 & 0.34 & 2.93 & 3.01 & 1.60 \\
\hline Total $\mathrm{Pb}\left(\mathrm{mg} \mathrm{kg}^{-1}\right)$ & 0.03 & 0.08 & 1.02 & 0.03 & 0.02 & 0.41 & 0.63 & 0.04 \\
\hline
\end{tabular}


and determined by Kjeldahl method (Subbaiah and Asija 1956). Available $\mathrm{P}$ was extracted with Olsen reagent in $0.5 \mathrm{M} \mathrm{NaHCO}_{3}$ of $\mathrm{pH} 8.5$; at a soil-extractant ratio of 1:20, extracted phosphorous was shaken for $20 \mathrm{~min}$ and measured colorimetrically (Olsen et al. 1954). Available K was extracted with neutral normal ammonium acetate $(\mathrm{pH} 7.0)$, shaken for $5 \mathrm{~min}$ at 220 oscillations per minute, filtered and measured by flame photometry (Toth and Prince 1949). Zn, $\mathrm{Cu}$, and $\mathrm{Fe}$ were analyzed with hot acid-extractable trace elements method (ICAP_7000 1994). In a microwave digestion unit (MARS), $0.2 \mathrm{~g}$ of soil was digested in $10 \mathrm{ml}$ of $\mathrm{HNO}_{3}$. Afterward, the sample was filtered and diluted five times with ultrapure water. The elements were estimated with the help of atomic absorption spectrometer. SOC was determined by dichromate oxidation (Walkley and Black 1934) and microbial biomass carbon (MBC) was measured by the fumigation-extraction method and calculated using the formula Biomass $C=\mathrm{EC} / \mathrm{kEc}$ where $\mathrm{kEc}$ is 0.38 (Vance et al. 1987).

Soil alkaline phosphatase was determined according to Tabatabai and Bremner (1969) and reported as g p-nitrophenol (p-NP) produced per gram dry weight of soil per hour. Soil dehydrogenase activity was determined by the reduction of triphenyltetrazolium chloride to triphenyl formazan (TPF) and reported as $\mu \mathrm{g}$ of TPF released per gram soil per hour (Casida et al. 1964). Soil urease activity was determined according to Fawcwtt and Scott (1960) and reported as $\mu \mathrm{g}$ of ammonia released per gram of soil per hour.

Basal soil respiration was done by alkali absorption method as explained by Stenberg et al. (1998). Twenty grams of soil sample after adjusting to $60 \%$ water holding capacity were incubated for 7 days at $28{ }^{\circ} \mathrm{C}$ to trap $\mathrm{CO}_{2}$ produced during the incubation period in $10 \mathrm{ml}$ of $0.5 \mathrm{~N} \mathrm{NaOH}$. The evolved $\mathrm{CO}_{2}$ was precipitated in $5 \mathrm{ml}$ of $\mathrm{BaCl}_{2}$ and determined by titrating with $0.5 \mathrm{~N} \mathrm{HCl}$ using phenolphthalein as indicator. The basal soil respiration was calculated as $\mathrm{g}$ of $\mathrm{CO}_{2}$ released per gram of soil per hour and metabolic quotient ( $\mathrm{qCO} 2)$ was calculated as the ratio of basal respiration rate ( $\mathrm{g} \mathrm{C}-\mathrm{CO}_{2}$ per hour) per unit of $\mathrm{MBC}$ of corresponding sample (Dilly and Munch 1998).

\section{Statistical analysis}

All data were statistically analyzed by two-way analysis of variance (ANOVA) using Microsoft Excel (Microsoft Office Professional Plus 2010, Version 14.07190.5000, Microsoft Corporation). Pearson's correlation analysis was performed to test relationships between variables and the figure was prepared using R studio (version 1.1.419). To study the relationship of observed soil variables and extraction of governing soil factors, principal component analysis was performed on correlated variables using statistical package SPSS Inc.
Released 2007. SPSS for Windows, Version 16.0. Chicago, SPSS Inc.

\section{Results and discussion}

This experimental study was conducted to find a mean to get an effective and efficient way to utilize agriculture waste for improving soil fertility. One of the principles of conservative agriculture is to apply permanent soil cover with crop residues or live mulch (Bot et al. 2005). The present study was an effort to interpret the efficiency of each organic soil cover through a comparative perception. It is possible that each organic amendment would confer distinct properties to the soil.

\section{Nutritional status}

The concentration of SOC significantly varied within all the organic amendments $(p<0.001)$ (Fig. 1a). T7, T6, and $\mathrm{T} 3$ had the maximum concentration with a highest average concentration of $20.29 \mathrm{~g} \mathrm{~kg}^{-1}$ in T7. It was followed by biochars of rice (T2) and wheat (T5) and then crop residues of rice (T1) and wheat (T4). The lowest percentage of SOC was observed in treatment $\mathrm{T} 8$ and control. The overall SOC concentration was observed to be in a decreasing order in all the amendments in all the sampling months. Available $\mathrm{N}$ concentration followed a similar trend of the presence of maximum concentration in composts of wheat, rice, and wheat + rice with the highest concentration in wheat compost. Soil with rice biochar had a higher concentration of available nitrogen than wheat biochar treatment (Fig. 1b). Between the residues, the wheat residue-treated soil had more available $\mathrm{N}$ content than that of rice residue which interestingly recorded the lowest concentration amongst all the organic amendment treatments. T8 (green manure) did not show any noticeable concentration shift in available $\mathrm{N}$. The highest concentration of available $\mathrm{P}$ was obtained in T6, followed by nearly equal concentration of available $\mathrm{P}$ in the $\mathrm{T} 4, \mathrm{~T} 7$, and $\mathrm{T} 8$ while among the treatments rice residue was recorded with least concentration (Fig. 1c). An increasing trend of available $\mathrm{K}$ was observed in the treatments T1, T2, and T3, respectively (Fig. 1d). A similar trend was found in the treatments T4, T5, and T6 although T8 had the lowest available K concentration. In the present study, it was observed that composts amended soil contained more organic matter than rest of the organic amendments, as attributed to a higher rate of organic matter decomposition in the soil. Crop residues when incorporated directly into the soil accelerate the biochemical and biological components of the carbon cycle in soil (Maithani et al. 1998). Similarly, green manure enhances organic matter in the soil, but in the form of non-decomposed vegetative matter as it aids 


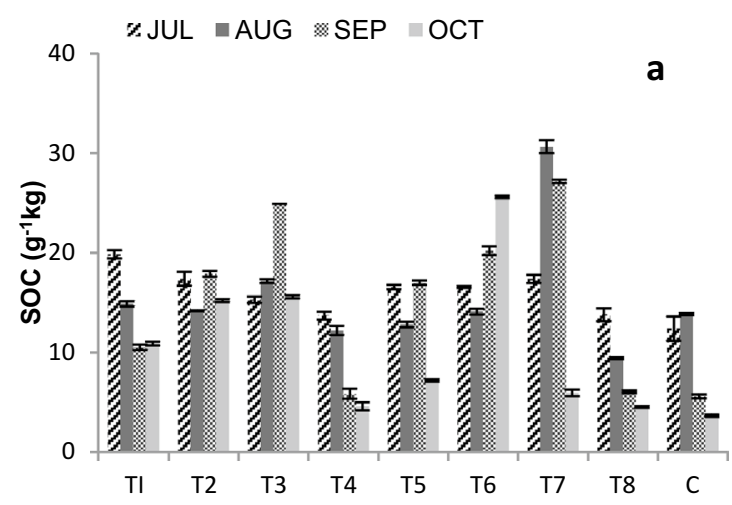

$\because \mathrm{JUL} \backsim \mathrm{AUG} \approx \mathrm{SEP} \approx \mathrm{OCT}$

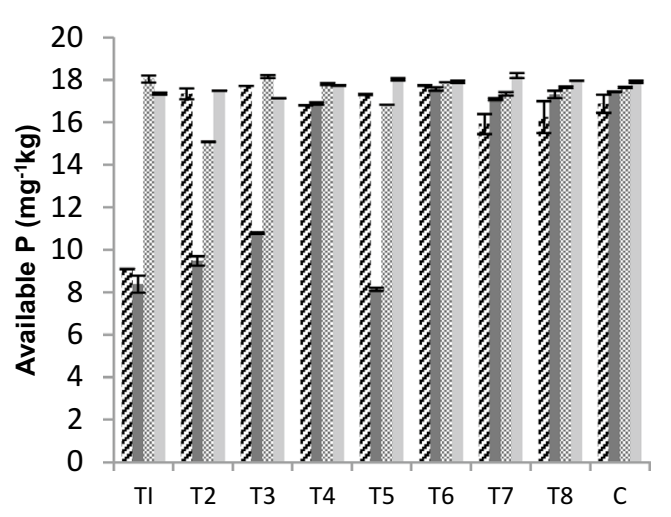

Fig. 1 Soil organic carbon (a), available nitrogen (b), phosphorus (c) and potassium (d) in organic amended soils under rice cultivation in July, August, September, and October. Means of three replicate values plotted and error bars indicate the standard error. T1, rice resi-

sudden release of nutrients into the soil but its uptake is slow by the following crop (Bot et al. 2005). The application of organic amendments in this study demonstrated a significant increase in the nutritional level of the test soil. However, it followed a similar trend of highest increase in composts, followed by biochars, crop residues, and then green manure, in organic carbon, available $\mathrm{N}$, available $\mathrm{P}$, and available $K$. The reason could be the presence of rich organic matter which governs the availability of major soil nutrients to the plants.

The soil samples from the organic amendments were analyzed for a secondary nutrient $\mathrm{Mg}$ and micronutrients $\mathrm{Cu}, \mathrm{Fe}$, and $\mathrm{Zn}$ (Fig. 2). There was a similar trend observed in all the treatments where the concentration of micronutrient increased initially and gradually declined after reaching maturity. In the case of $\mathrm{Cu}$ (Fig. 2a) and Fe (Fig. 2b), the implications of organic amendments and crop growth stages were evident significantly in its concentration $(p<0.05)$. The concentration of $\mathrm{Cu}$ was highest in T5 $\left(0.942 \mathrm{mg} \mathrm{kg}^{-1}\right)$ and lowest in the control soil C
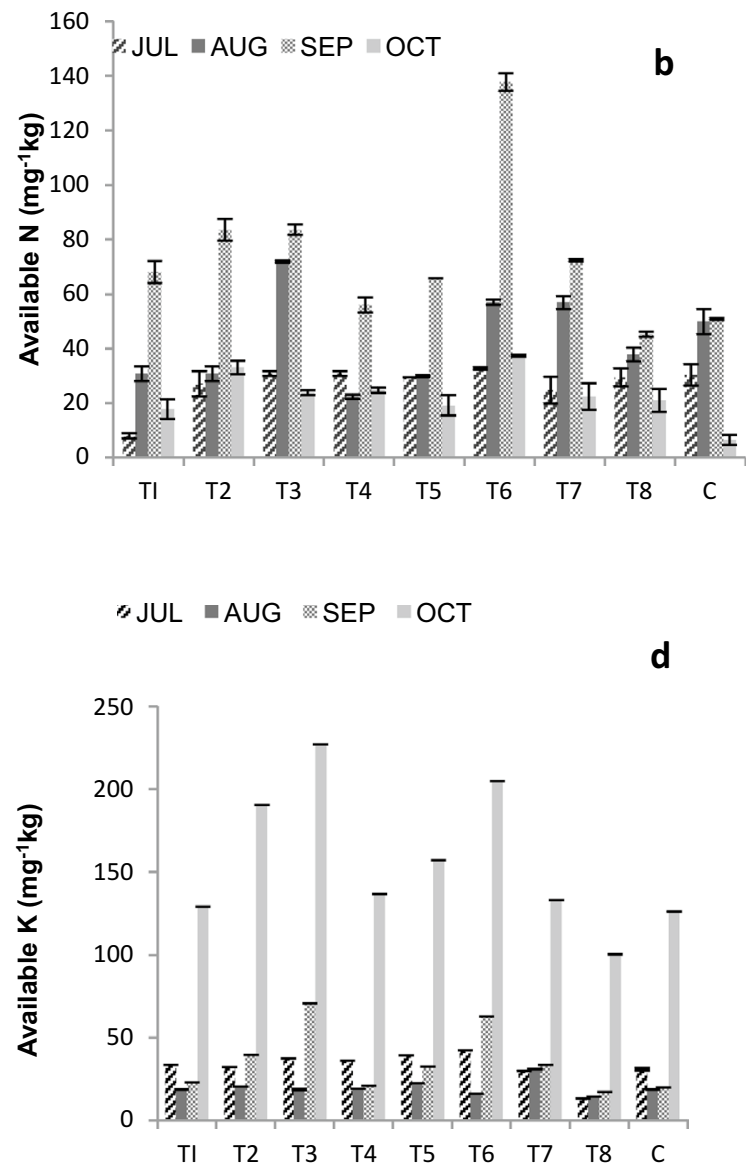

due; $\mathrm{T} 2$, rice biochar; $\mathrm{T} 3$, rice compost; $\mathrm{T} 4$, wheat residue; $\mathrm{T} 5$, wheat biochar; T6, wheat compost; $\mathrm{T} 7$, wheat + rice compost; $\mathrm{T} 8$, green manure; $\mathrm{C}$, no amendment

$\left(0.757 \mathrm{mg} \mathrm{kg}^{-1}\right)$. Fe concentration followed a decreasing order of $\mathrm{T} 2>\mathrm{T} 5>\mathrm{T} 1>\mathrm{T} 3>\mathrm{T} 7>\mathrm{T} 4>\mathrm{T} 6>\mathrm{C}>\mathrm{T} 8$ with the highest concentration of $133.21 \mathrm{mg} \mathrm{kg}^{-1}$ in $\mathrm{T} 2$ and lowest in $\mathrm{T} 8127.99 \mathrm{mg} \mathrm{kg}^{-1}$. However, $\mathrm{Mg}$ (Fig. 2c) and $\mathrm{Zn}$ (Fig. 2d) showed no any significant change in response to organic treatments but significantly responded to crop growth stages $(p<0.05)$. The mean values of $\mathrm{Zn}$ ranged from $3.81 \mathrm{mg} \mathrm{kg}^{-1}$ in $\mathrm{T} 3$ to $3.28 \mathrm{mg} \mathrm{kg}^{-1}$ in control soil, whereas in $\mathrm{Mg}$ it was lowest in $\mathrm{T} 1\left(66.0 \mathrm{mg} \mathrm{kg}^{-1}\right)$ and highest in $\mathrm{T} 3\left(70.89 \mathrm{mg} \mathrm{kg}^{-1}\right)$. In the present study, there were no remarkable variations observed in the micronutrient status among the organically treated soil. But, there was an evident increase in the $\mathrm{Fe}$ and $\mathrm{Cu}$ concentration of the organic soils compared with control soil. Fe is present in the organic soils in the form of chelates as iron oxides and is also known to affect the retention and mobility of other elements in the soil (Silveira et al. 2003). Cu can co-exist with $\mathrm{Fe}$ in the soil as its constituent which further explains the positive correlation of $\mathrm{Cu}$ with $\mathrm{Fe}\left(r^{2}=0.949\right.$, Fig. 6) (Singh and Gilkes 1992). Nonetheless, visible 

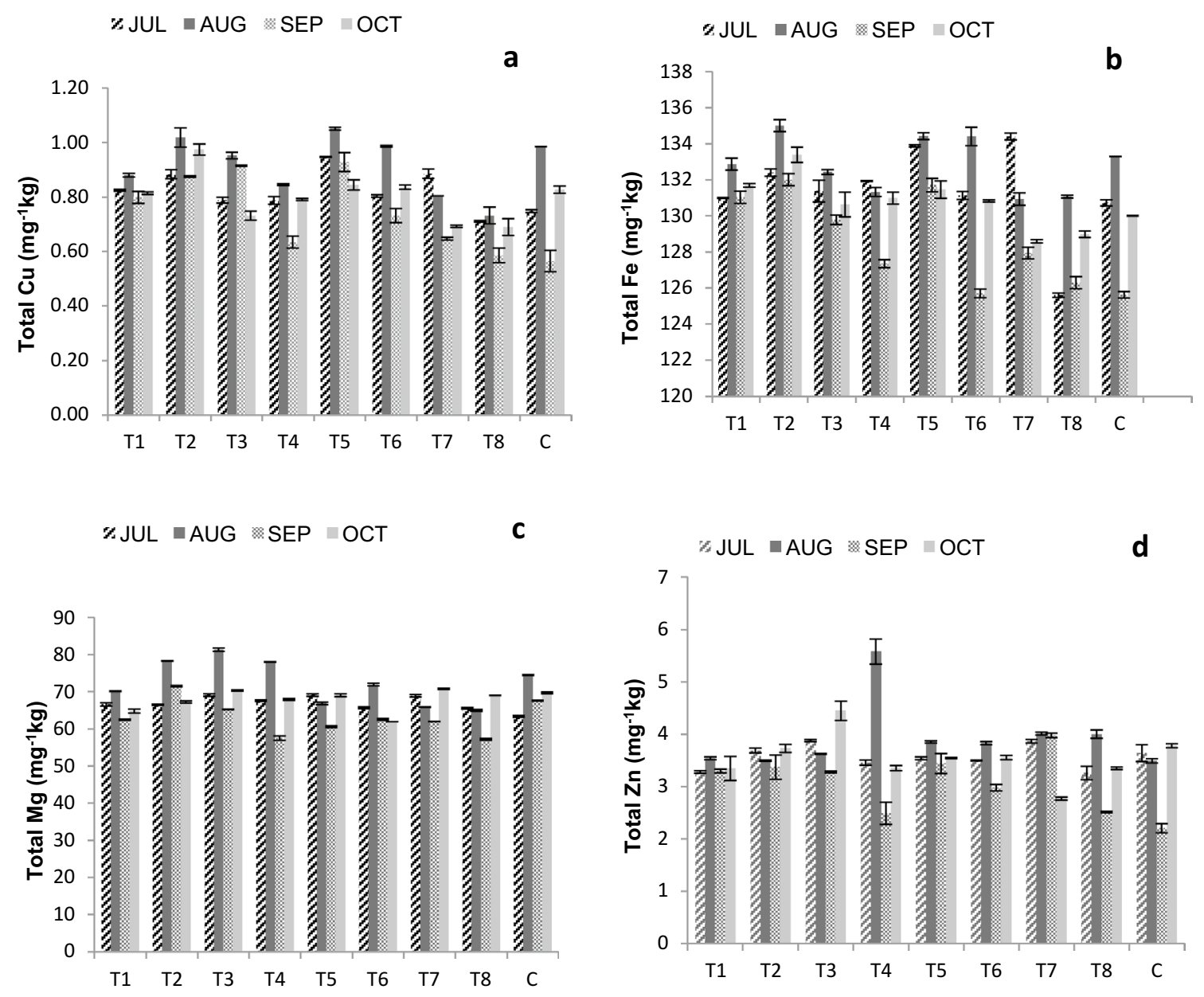

Fig. 2 Micronutrient concentration of a total copper, $\mathbf{b}$ total iron, $\mathbf{c}$ total magnesium and $\mathbf{d}$ total zinc in organic amended soils under rice cultivation in July, August, September, and October. Means of three replicate values plotted and error bars indicate the standard error. T1,

rice residue; T2, rice biochar; $\mathrm{T} 3$, rice compost; T4, wheat residue; T5, wheat biochar; T6, wheat compost; T7, wheat + rice compost; T8, green manure; $\mathrm{C}$, no amendment

variation in micronutrients concentration was observed across growth stages of the rice crop (Tamilselvi et al. 2015).

\section{Microbial biomass carbon and microbial quotient}

Microbial biomass carbon, the living component of the soil which links soil nutrients to energy dynamics, has been accepted as a sensitive indicator that responds to even shortterm nutritional and environmental changes in soil (Haynes 2008). There was a significant effect $(p<0.01)$ of organic amendments in MBC detected in the soil across different seasons representing growth features of rice crop (Fig. 3). In this study, the mean soil microbial biomass carbon for all the treatments ranged from $238 \mu \mathrm{g} \mathrm{g}^{-1}$ (T1) to $665 \mu \mathrm{g} \mathrm{g}^{-1}$ (T7). In the treatments $\mathrm{T} 3, \mathrm{~T} 6$ and $\mathrm{T} 7, \mathrm{MBC}$ concentration gradually increased $\left(240 \mu \mathrm{g} \mathrm{g}^{-1}, 346 \mu \mathrm{g} \mathrm{g}^{-1}\right.$ and $335 \mu \mathrm{g} \mathrm{g}^{-1}$, respectively) during sowing and then slightly declined at the

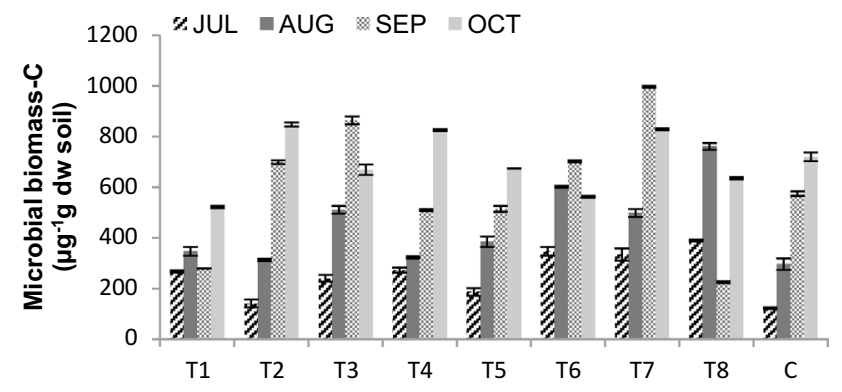

Fig. 3 Microbial biomass carbon in organic amended soils under rice cultivation in July, August, September, and October. Means of three replicate values plotted and error bars indicate the standard error. T1, rice residue; T2, rice biochar; $\mathrm{T} 3$, rice compost; $\mathrm{T} 4$, wheat residue; T5, wheat biochar; T6, wheat compost; T7, wheat + rice compost; T8, green manure; $\mathrm{C}$, no amendment 
time of harvest. While in rest of the treatments, it inclined to the peak till harvesting season. The highest increase of 35\% was obtained in $\mathrm{T} 7$ followed by T3 and T6 of $25 \%$ and $22 \%$, respectively, over the mean value of $\mathrm{MBC}$ concentration of control soil. The mean value of T8 was $14 \%$ more than the control soil. Crop residue amendments T1 and T4 showed lower concentration of $238 \mu \mathrm{g} \mathrm{g}^{-1}$ and $427 \mu \mathrm{g} \mathrm{g}^{-1}$ of carbon, respectively, than the control soil. In the present study, compost treatments had a greater influence on MBC concentration (Hu et al. 2011; Chinnadurai et al. 2014; Tamilselvi et al. 2015). In addition to that T7, compost of wheat + rice was most responsive to a nutritional change in soil caused by its addition. It shows that among various composts, the effectiveness depends on the richness and nutritional quality of the compost, as the inputs used to prepare compost impart distinct nutritional character to the prepared product. Green manure and crop residue amendments performed relatively lower than composts, the study of (Liu et al. 2017) supported similar results where $\mathrm{mg} \mathrm{kg}^{-1}$ of MBC of NPK plus green manure and NPK plus straw was significantly less than NPK plus pig manure. Soil amended with biochar of both wheat and rice had higher MBC content than control, crop residues, and green manure. However, the results are in contradiction to the study done by Zavalloni et al. (2011), who recorded significant increase of $M B C$ by wheat straw than biochar. Such differential observation could be attributed to composition and application rate of biochar that influences the soil physiology.

Microbial respiration is a measure of $\mathrm{CO}_{2}$ production in the soil which interpreted along with $\mathrm{MBC}$ gives an ecophysiological index, which can be considered as a true representation of microbiological activities in soil. Irrespective of organic treatments, soil respiration rate followed an increasing trend in sowing season and declined in harvesting season (Fig. 4a). An increase in soil respiration during the sowing

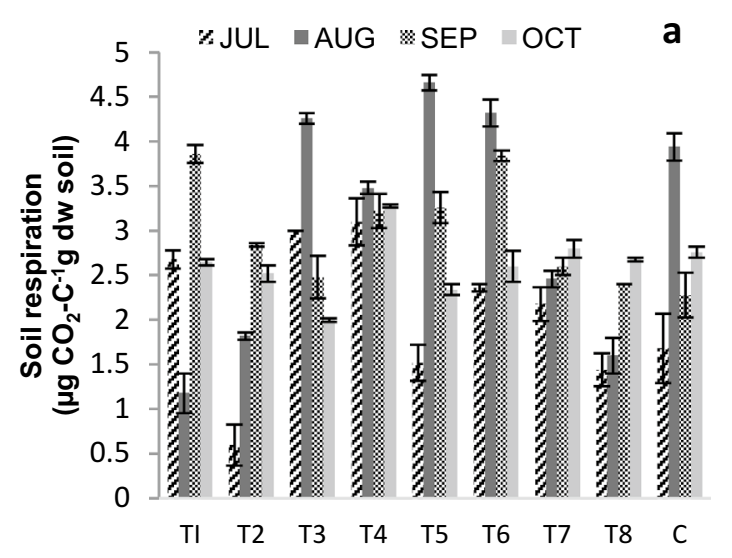

Fig. 4 a Basal soil respiration and $\mathbf{b}$ microbial quotient in organic amended soils under rice cultivation in July, August, September, and October. Means of three replicate values plotted and error bars indi- season of the crop indicates a positive reaction to freshly added nutrient-rich organic matter (Singh and Cowie 2011). The recorded mean values showed variation in the soil respiration as influenced by different organic amendments in the soil. An increase of $23 \%$ and $22 \%$ was seen in T6 and T4, respectively. Overall, an increased percent variation was observed in the order of $\mathrm{T} 6>\mathrm{T} 4>\mathrm{T} 5>\mathrm{T} 3>\mathrm{T} 1>\mathrm{T} 7>\mathrm{T} 8>$ T2. Metabolic quotient calculated as a ratio of soil respiration to MBC (Fig. 4b) shows significant difference within organic treatments $(p<0.05)$ as well as crop growth stages $(p<0.001)$. Minimum average value of all growing seasons was recorded for organic treatments $\mathrm{T} 1$ and $\mathrm{T} 7(4.28 \mu \mathrm{g}$ $\mathrm{C}-\mathrm{CO}_{2} / \mu \mathrm{g} \mathrm{C} \mathrm{MBC}$ and $4.35 \mu \mathrm{g} \mathrm{C}-\mathrm{CO}_{2} / \mu \mathrm{g} \mathrm{C} \mathrm{MBC}$, respectively), while the highest value of $8.72 \mu \mathrm{g} \mathrm{C}-\mathrm{CO}_{2} / \mu \mathrm{g} \mathrm{C} \mathrm{MBC}$ was observed in the control soil. Metabolic quotient explains the efficacy of organic matter utilization by microorganisms for their energy requirement maintenance (Moscatelli et al. 2005). It showed an initial increasing trend when the fresh organic matter was added to the soil and, therefore, there was higher respiration rate per unit of microbial biomass (Odum 2014). There was a significant difference amongst organic treatments as well as crop stages $(p<0.05)$. The presence of its lower mean value for all the organic amendments than control soil indicates effective utilization of carbon substrate vis-à-vis greater efficiency of microorganism, which resonates a similar viewpoint shared by Flie $\beta$ bach and Mäder (1997). Comparatively, crop residue amended soils recorded high $\mathrm{qCO}_{2}$ than other organic treatments which is consistent with the values of less organic carbon and low MBC. It explains the ineffective cycling of carbon in the soil with significantly lower microbial load present, amended with rice and wheat residue. The difference in mean values of $\mathrm{qCO}_{2}$ in all the organic treatments reflects the substrate utilization efficiency of the distinct microbial communities present in each organic system. Compost only being used when

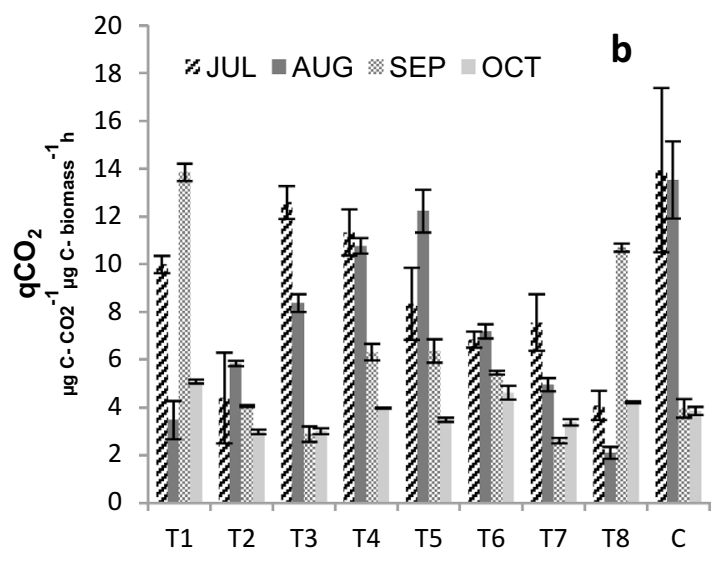

cate the standard error. $\mathrm{T} 1$, rice residue; $\mathrm{T} 2$, rice biochar; $\mathrm{T} 3$, rice compost; T4, wheat residue; T5, wheat biochar; T6, wheat compost; $\mathrm{T} 7$, wheat + rice compost; $\mathrm{T} 8$, green manure; $\mathrm{C}$, no amendment 
matured has the least value of $\mathrm{qCO}_{2}$ whereas the freshly added crop residues enable a higher rate of microbial respiration that mineralize organic matter by the native microbial population.

\section{Soil enzymatic activities}

Soil enzymatic activity has been a real-time indicator of the functional potentiality of microorganisms. Organic farming induces changes in the microbial aspect of the soil resulting in functional changes in agro-ecosystems, which corroborates with previous studies of Bonanomi et al. (2016) and $\mathrm{Gu}$ et al. (2009). Dehydrogenase is often most studied enzyme because of its occurrence in every viable microbial cell that determines the overall microbiological activity in the soil (Nannipieri et al. 2011). Dehydrogenase activity responded significantly $(p<0.001)$ across organic treatments and stages of crop growth and their interactions in soil (Fig. 5a). For example, dehydrogenase showed an increasing trend from sowing season to the vegetative stage, reached the peak in maturation stage and started decreasing at harvesting. The similar trend was observed in almost all the given treatments. Few authors (Instytut Agrofizyki w Lublinie et al. 2000; Tripathi et al. 2007) have reported the seasonal activity of dehydrogenase in early autumn and have mentioned highest values obtained in July to September which is in line with the results obtained in the present study. The reason is also due to the presence of optimum temperature during July-September (wettest months) that is congenial for the growth and functioning of soil microbes (Woli et al. 2012). A highest of fivefold increase in the value of dehydrogenase activity $(5.1 \mu \mathrm{g}$ of TPF released per gram of soil per day) was registered in treatment $\mathrm{T} 7$ over the control. Threefold increase in $\mathrm{T} 3$ and $\mathrm{T} 6$ treatments and the lowest (1.2 times)
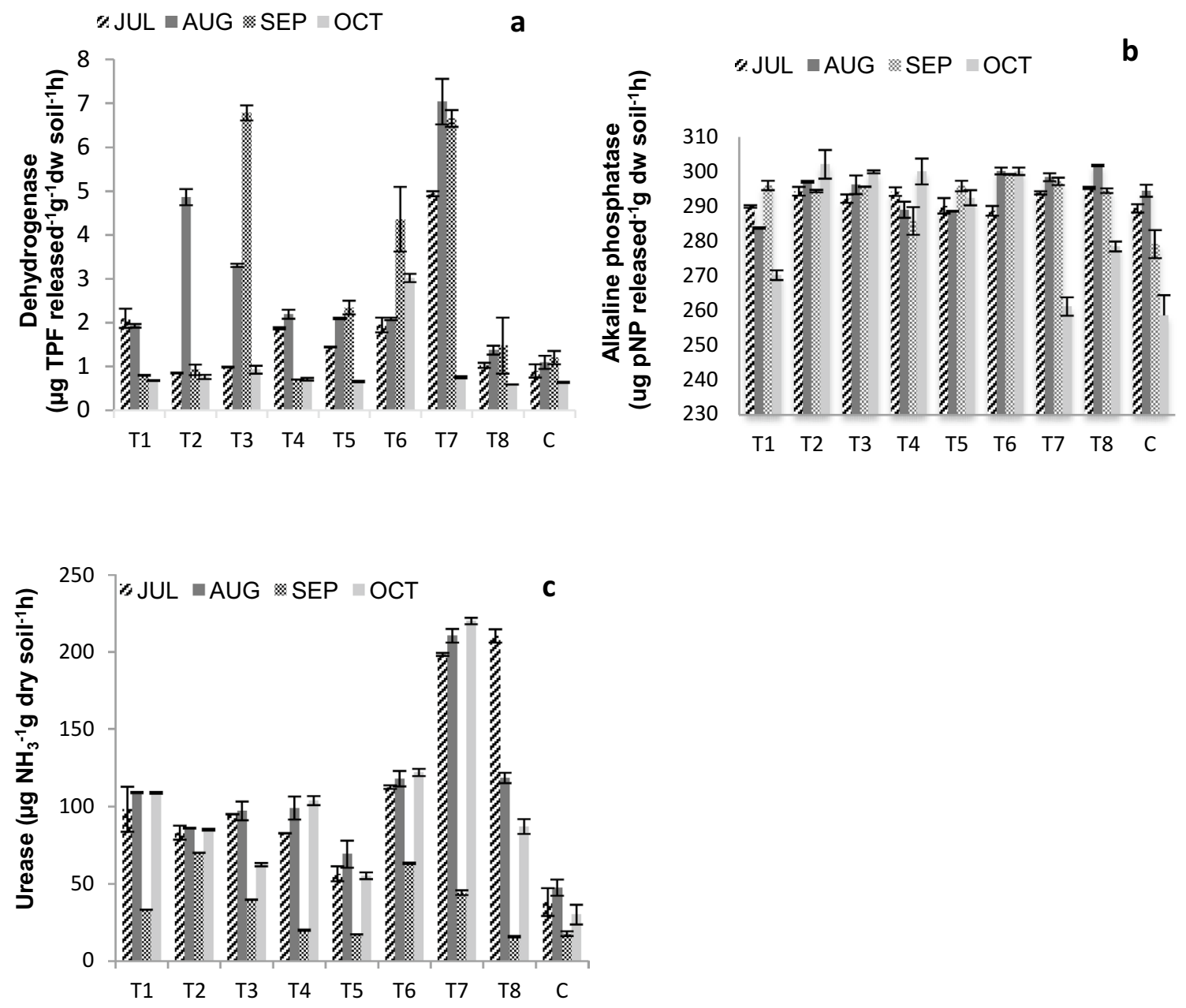

Fig. 5 Enzymatic activity a dehydrogenase, b alkaline phosphatase, and $\mathbf{c}$ urease in organic amended soils under rice cultivation in July, August, September, and October. Means of three replicate values plotted and error bars indicate the standard error. T1, rice residue; T2,

rice biochar; $\mathrm{T} 3$, rice compost; $\mathrm{T} 4$, wheat residue; $\mathrm{T} 5$, wheat biochar; $\mathrm{T} 6$, wheat compost; $\mathrm{T} 7$, wheat + rice compost; T8, green manure; $\mathrm{C}$, no amendment 
response was observed in green manure treatment. Several authors have reported similar results with the present findings of higher dehydrogenase activity in organically treated soils (Chang et al. 2014; Macci et al. 2012; Martens et al. 1992). The oxidoreductase reaction carried by dehydrogenase in the soil largely depends on the availability of substrate. Thus, the presence of easily available high organic matter substrate in compost and biochar positively affected the microbial biomass and in turn microbial activity.

Alkaline phosphatase (ALP) is the key enzyme in phosphorous transformation cycle because of its role in mineralizing organic phosphorous into plant available phosphorous (Richardson 2001). The ALP enzyme activity showed significant variation $(p<0.001)$ due to organic amendments and crop stages (Fig. 5b). The range of alkaline phosphatase activity varied from $258.77 \mu \mathrm{g}$ PNP released per gram soil per hour in control soil to $302.2 \mu \mathrm{g}$ PNP released per gram soil per hour in $\mathrm{T} 2$ treatment. All the organic amendments registered ALP activity at par with the control soil. While ALP activity depends on several factors including soil properties, organic amendments, and microbial interactions (Speir and Ross 1978), Sakurai et al. (2008) and Zhang et al. (2016) validated that organic fertilizers are rich in organic matter and enhances alkaline phosphatase activity. However, quality and quantity of organic amendment affect the overall microbial dynamics of the soil, as mentioned in the study of Elzobair et al. (2016) who stated the contrasting effects of biochar and manure on microbial activities and concluded that manure even in short term enhances enzymatic activity in comparison to biochar. The slightly opposite outcome in contrast to present study was reported by Kashyap and Khokhar (2017) where ALP activity was in the order of wheat straw $>$ Farm Yard Manure $>$ Green manure. The results infer that organic fertilizers enhance the microbial activity in the soil, but the degree of variation depends on the interaction between microbial communities and the substrate quality in the soil.
Urease activity is widely used to assess the impact of soil management practices on soil quality (Diaz-Marcote et al. 1995). In the present study, urease activity showed a significant difference in soil treated with amendments $(p<0.001)$ at each crop growth stage over the control soil (Fig. 5c) which was also consistent with the results of Liang et al. (2003). T6, T7, and T8 recorded greater urease activity; a fivefold increase was observed in wheat-rice compost (T7) and the least in the T5 over the control. Higher concentration of nitrogen in soil stimulates the urease activity amended with different carbon substrates (Shukla and Varma 2011). The same can be interpreted with the results in the present study where $\mathrm{T} 8$ and $\mathrm{T} 7$ recorded greater urease activity corresponding to high $\mathrm{N}$ concentration. However, several authors have reported the inhibitory effect of inorganic nitrogen fertilizers on urease enzyme (Bremner and Douglas 1971; Ajwa et al. 1999). In the present study, no urea was added and each organically amended soil showed enhanced urease activity relative to control soil. However, the duration and rate of application of organic fertilizers cannot be ignored, before concluding if it has inhibitory effects or not.

\section{Crop response to organic amendments}

The rice plants from the treatment pots were analyzed for parameters that represented the growth attributes of the plant in response to organic amendments (Table 3). A significant effect of organic treatments was observed in plant height $(p<0.001)$ as well as total biomass $(p<0.001)$. Similar result of significance in maize biomass was obtained by Pampuro et al. (2017) on application of pig slurry compost. The noticeable alteration was observed in the rice plants of compost-treated amendments $\mathrm{T} 6, \mathrm{~T} 3$, and $\mathrm{T} 7$ with respect to plant height which was $86 \mathrm{~cm}, 78.67 \mathrm{~cm}$, and 78.33 with corresponding biomass of $73.17 \mathrm{gm}, 69 \mathrm{gm}$ and $59 \mathrm{gm}$. in T6, T3, and T7, respectively. Spike length also showed significant change $(p<0.005)$ with the highest mean value of $22 \mathrm{~cm}$

Table 3 Influence of organic treatments on crop growth parameters

\begin{tabular}{llcccc}
\hline Treatment & Tillers (in numbers) & Spikes (in numbers) & Spike length $(\mathrm{cm})$ & Plant height $(\mathrm{cm})$ & Total biomass $(\mathrm{gm})$ \\
\hline T1 & $12.67( \pm 1.45)$ & $10.33( \pm 3.48)$ & $15.67( \pm 0.67)$ & $68.00( \pm 1.73)$ & $28.83( \pm 1.36)$ \\
T2 & $15.00( \pm 1.15)$ & $12.33( \pm 0.67)$ & $17.33( \pm 0.88)$ & $67.00( \pm 1.53)$ & $50.83( \pm 2.95)$ \\
T3 & $18.33( \pm 0.88)$ & $17.00( \pm 0.58)$ & $22.00( \pm 0.00)$ & $78.67( \pm 1.76)$ & $69.00( \pm 2.89)$ \\
T4 & $15.00( \pm 6.02)$ & $12.67( \pm 4.67)$ & $17.67( \pm 0.33)$ & $69.67( \pm 3.71)$ & $62.83( \pm 0.44)$ \\
T5 & $15.00 \pm 4.50$ & $14.00( \pm 4.58)$ & $19.67( \pm 0.67)$ & $70.67( \pm 2.03)$ & $61.33( \pm 1.20)$ \\
T6 & $20.00( \pm 2.08)$ & $20.33( \pm 0.33)$ & $19.00( \pm 2.08)$ & $86.00( \pm 5.51)$ & $73.17( \pm 3.56)$ \\
T7 & $16.00( \pm 2.64)$ & $12.33( \pm 3.28)$ & $19.67( \pm 0.33)$ & $88.33( \pm 0.88)$ & $59.33( \pm 4.18)$ \\
T8 & $14.67( \pm 3.28)$ & $9.67( \pm 1.45)$ & $19.67( \pm 0.33)$ & $75.67( \pm 1.20)$ & $44.67( \pm 1.86)$ \\
C & $13.33( \pm 0.66)$ & $11.00( \pm 0.00)$ & $18.33( \pm 0.33)$ & $75.67( \pm 2.33)$ & $30.17( \pm 4.97)$ \\
\hline
\end{tabular}

Mean of five replicate values plotted and values in paranthese indicate the standard error. T1, rice residue; T2, rice biochar; T3, rice compost; T4, wheat residue; T5, wheat biochar; T6, wheat compost; T7, wheat + rice compost; T8, green manure; C, no amendment 
in T6. Tillers and spike numbers did not show any significant variation due to organic amendments. Data presented in Fig. 6 showed significant positive correlation of number of tillers with number of spikes $\left(r^{2}=0.928, p=0.0001\right)$, AN $\left(r^{2}=0.944, p=0.0001\right)$ and AK $\left(r^{2}=0.788, p=0.006\right)$. A number of spikes were strongly correlated to total biomass $\left(r^{2}=0.804, p=0.005\right)$. Plant height was significantly correlated to dehydrogenase activity $\left(r^{2}=0.777, p=0.007\right), \mathrm{MBC}$ $\left(r^{2}=0.787, p=0.006\right)$ and $\mathrm{qCO}_{2}\left(r^{2}=0.759, p=0.009\right)$. The total biomass was positively correlated to alkaline phosphatase activity $\left(r^{2}=0.767, p=0.008\right)$. Nearly, all the considered crop growth attributes were significantly correlated to available $\mathrm{N}$ and $\mathrm{K}$. The cumulative response of crop growth attributes in all the organic amendments-treated soil signifies an increase in percent variation above $9 \%$ to up to $47 \%$ over the control soil. Gwenzi et al. (2016) proclaimed similar results of increase in maize growth of $42-53 \%$ in sewage sludge and sewage biochar, respectively.

Analysis of principal components was done on nearly correlated soil parameters to determine the governing factors causing change after organic amendment. Four components with eigen value $>1$ having a cumulative percentage of $78.65 \%$ were extracted. PC1 and PC2 were responsible for $54.17 \%$ of variance out of which PC1 and PC2 contribute $30.48 \%$ and $23.68 \%$, respectively. PC3 showed $12.76 \%$ and PC4 showed $11.71 \%$ variation (Table 4). Among the considered variables, DHA, ALP, SOC, AK, AN, and MBC had measure contribution to PC1, while URE and $\mathrm{qCO}_{2}$ contributed to PC2. This clearly indicates that any change in the rate of input caused by environment or nutrient management affects the stored carbon in soil nutrient cycling (Carter and Gregorich 2006). Application of organic amendments improves the soil quality and enhances the crop growth and yield (Dahama 1997; Bonanomi et al. 2016; Gwenzi et al. 2016). But different crop species respond differently to the organic amendments applied to the soil (Roy et al. 2010). In the present work, the rice plants responded to all sorts of organic amendments across different growth periods.

Murphy et al. (2016) emphasized that crop residue retention although enhanced soil properties, but did not significantly increased the total biomass of crop. The reason for the varied crop growth response to residue incorporation in soil could, therefore, be attributed to the chemical composition of the residue which determines its decomposability and
Fig. 6 Pearson correlation plot between the crop growth attributes and soil parameters: number of tillers (NT), number of spikes (NS), spike length (SL), plant height $(\mathrm{PH})$, total biomass (TB), DHA (dehydrogenase), urease (URE), alkaline phsphatase (ALP), microbial biomass carbon (MBC), $\mathrm{qCO}_{2}$ (microbial quotient), basal soil respiration (BSR), soil organic carbon (SOC), available nitrogen (AN), available phosphorous (AP), available potassium (AK). Blue color indicates positive correlation and red color indicates negative correlation; size of each respective circle indicates the extent of correlation

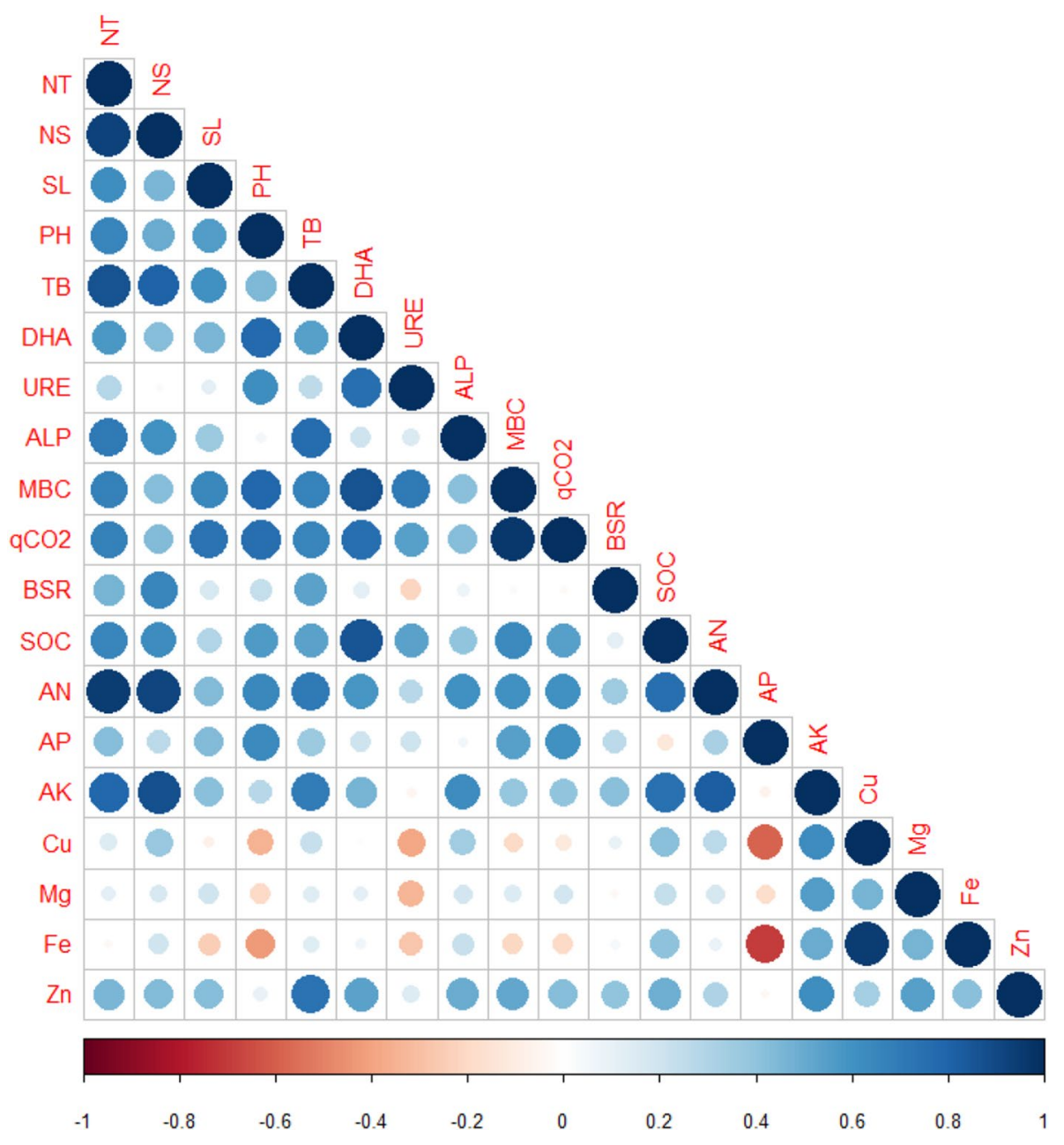


Table 4 Principal component analysis of soil quality parameters for the 4 PCs

\begin{tabular}{lcccc}
\hline Principal components & \multicolumn{1}{l}{ PC1 } & \multicolumn{1}{l}{ PC2 } & \multicolumn{1}{l}{ PC3 } & \multicolumn{1}{l}{ PC4 } \\
\hline Eigen value & 2.744 & 2.131 & 1.149 & 1.055 \\
Variability\% & 30.48 & 23.68 & 12.76 & 11.71 \\
Cumulative\% & 30.48 & 54.17 & 66.79 & 78.65 \\
Eigen vectors & & & & \\
DHA & $\mathbf{0 . 7 0 0}$ & 0.329 & -0.126 & -0.323 \\
URE & -0.157 & $\mathbf{0 . 5 9 5}$ & $\mathbf{0 . 6 8 4}$ & -0.191 \\
ALP & 0.541 & 0.327 & -0.144 & 0.284 \\
MBC & 0.402 & -0.825 & 0.009 & -0.212 \\
SOC & $\mathbf{0 . 8 0 0}$ & 0.434 & 0.116 & -0.191 \\
AK & $\mathbf{0 . 7 0 8}$ & -0.006 & $\mathbf{0 . 4 2 2}$ & 0.126 \\
AN & $\mathbf{0 . 7 3 1}$ & -0.101 & -0.323 & 0.385 \\
AP & 0.099 & -0.459 & $\mathbf{0 . 5 5 7}$ & $\mathbf{0 . 5 8 2}$ \\
qCO & -0.299 & $\mathbf{0 . 6 8 8}$ & -0.198 & $\mathbf{0 . 4 9 8}$ \\
\hline
\end{tabular}

$D H A$ dehydrogenase, $U R E$ urease, $A L P$ alkaline phsphatase, $M B C$ microbial biomass carbon, $Q_{2} O_{2}$ microbial quotient, $S O C$ soil organic carbon, $A N$ available nitrogen, $A P$ available phosphorous, $A K$ available potassium

${ }^{a}$ Bold numeric values are the key variables explaining the corresponding PCs

nutrient availability to the plant (Rousk et al. 2010). Both wheat and rice straw have distinct chemical compositions that govern their decomposition rate. Rice residue being rich in cellulose takes more time to degrade. A similar fate was observed with organic amendments composed of wheat. Goyal et al. (2009) reported a positive effect of rice straw compost on rice yield.

Biochar gave high results than crop residue treatment with respect to crop growth. Yadav et al. (2016) observed $20 \%$ increase in plant height of test crop (Cicer) treated with pyrolyzed biochar. On the contrary, Gwenzi et al. (2016) reported that biochar alone is not a fertilizer and, therefore, did not show any significant difference in plant height of maize crop. Biochar addition to soil results in an increase in carbon content of the soil which corresponds to the increased total biomass of plants.

In the present study, compost showed considerably high plant growth response in comparison to biochar and crop residues including green manure amendments. The higher nutrient availability enhances plant accessible nutrient uptake which is generally reasoned for its considerable performance. Significantly less biomass increase in control crop is due to negative nutrient balance (Srivastava et al. 2010). Three forms of organic composts consisting of rice (T3), wheat (T6), and wheat-rice (T7) were used. Compared to other composts, the effect of rice compost on paddy cultivated soil was less significant, but it showed equitable plant growth response with $\mathrm{T} 6$ and $\mathrm{T} 7$. This demonstrates that there is no exact direct relation between quality of organic amendment and its perceived effect on plant growth within the same form of amendments. Thus, it is a contrary that soil qualities are evaluated on the basis of comparative nutritional increments and microbial indicators, but when its effect is seen on plant growth and yield, contrasting results could be obtained as well.

\section{Conclusion}

This study demonstrated that different forms of organic amendments show varied results in terms of soil quality and crop growth. Compost being highly decomposed in nature reacts in a short time to bring change in soil properties. Therefore, composts of wheat and wheat + rice stimulated positive changes in the soil as well as plant quality. Although biochar performed somewhat in between compost and crop residue amendments, various studies have reported that biochar is known to work well in coordination with organic fertilizers than used solely. In the present study, crop residues showed least significant change to soil conditioning and negatively to crop growth while its long-term effect needs to be studied before declaring its low workability. The purview of application of rice and wheat agriculture waste as organic amendments was done to assess the sustainability of its reusability. From this perspective, using previous crop waste to improve soil condition for next crop is highly feasible. It improved the overall nutritional quality and the microbial dynamics of the soil. From the observed results, it is concluded that application of wheat compost and wheat + rice compost serves the best farming option for sustainable rice agrosystem in hilly areas. This attempt was a short-term study but in situ long-term studies are, however, required to develop an optimal organic treatment for a specific crop keeping in mind the requirements of soil health.

Acknowledgements The authors gratefully acknowledge the University Grants Commission, New Delhi, India for funding the research project with Doon University.

\section{Compliance with ethical standards}

Conflict of interest The authors declare that they have no conflict of interest.

Open Access This article is distributed under the terms of the Creative Commons Attribution 4.0 International License (http://creativeco mmons.org/licenses/by/4.0/), which permits unrestricted use, distribution, and reproduction in any medium, provided you give appropriate credit to the original author(s) and the source, provide a link to the Creative Commons license, and indicate if changes were made. 


\section{References}

Ajwa HA, Dell CJ, Rice CW (1999) Changes in enzyme activities and microbial biomass of tallgrass prairie soil as related to burning and nitrogen fertilization. Soil Biol Biochem 31:769-777. https ://doi.org/10.1016/s0038-0717(98)00177-1

Bonanomi G, De Filippis F, Cesarano G et al (2016) Organic farming induces changes in soil microbiota that affect agro-ecosystem functions. Soil Biol Biochem 103:327-336. https://doi. org/10.1016/j.soilbio.2016.09.005

Bot A, Benites J, Food and Agriculture Organization of the United Nations (2005) The importance of soil organic matter : key to drought-resistant soil and sustained food production. Food and Agriculture Organization of the United Nations, Rome

Bremner JM, Douglas LA (1971) Inhibition of urease activity in soils. Soil Biol Biochem 3:297-307. https://doi.org/10.1016/00380717(71)90039-3

Carter, Gregorich E (2006) Soil sampling and methods of analysis. CRC Press, Florida

Casida L, Klein D, Santoro T (1964) Soil dehydrogenase activity. Soil Sci 98:371-376

Chang EH, Wang CH, Chen CL, Chung RS (2014) Effects of longterm treatments of different organic fertilizers complemented with chemical $\mathrm{N}$ fertilizer on the chemical and biological properties of soils. Soil Sci Plant Nutr 60:499-511. https://doi. org/10.1080/00380768.2014.917333

Chinnadurai C, Gopalaswamy G, Balachandar D (2014) Impact of long-term organic and inorganic nutrient managements on the biological properties and eubacterial community diversity of the Indian semi-arid Alfisol. Arch Agron Soil Sci 60:531-548. https ://doi.org/10.1080/03650340.2013.803072

Dahama AK (1997) Organic farming for sustainable agriculture. In: Dahama AK (ed) Google books. Agro Botanical Publishers, Rajasthan

Diaz-Marcote I, Polo A, Ceccanti B (1995) Enzymatic activities in a soil amended with organic wastes at semiarid field conditions. Arid Soil Res Rehabil 9:317-325. https://doi.org/10.1080/15324 989509385900

Dilly O, Munch J-C (1998) Ratios between estimates of microbial biomass content and microbial activity in soils. Biol Fertil Soils 27:374-379. https://doi.org/10.1007/s003740050446

Elliot LF, McCalla TM, Waiss A (1978) Phytotoxicity associated with residue management. In: Oschwald WR (ed) Crop residue management systems. American Society of Agronomy, Madison WI, pp 131-146

Elzobair KA, Stromberger ME, Ippolito JA, Lentz RD (2016) Contrasting effects of biochar versus manure on soil microbial communities and enzyme activities in an aridisol. Chemosphere. https:// doi.org/10.1016/j.chemosphere.2015.06.044

Fawcwtt JK, Scott JE (1960) A rapid and precise method for the determination of urea. J Clin Pathol 13:156-159

Fließbach A, Mäder P (1997) Carbon source utilization by microbial communities in soils under organic and conventional farming practice. Microbial communities. Springer, Berlin, pp 109-120

Goyal S, Singh D, Suneja S, Kapoor KK (2009) Effect of rice straw compost on soil microbiological properties and yield of rice. Indian J Agric Res 43:263-268

Gu Y, Zhang X, Tu S, Lindström K (2009) Soil microbial biomass, crop yields, and bacterial community structure as affected by long-term fertilizer treatments under wheat-rice cropping. Eur J Soil Biol 45:239-246. https://doi.org/10.1016/j.ejsobi.2009.02.005

Gwenzi W, Muzava M, Mapanda F, Tauro TP (2016) Comparative short-term effects of sewage sludge and its biochar on soil properties, maize growth and uptake of nutrients on a tropical clay soil in
Zimbabwe. J Integr Agric 15:1395-1406. https://doi.org/10.1016/ s2095-3119(15)61154-6

Harris JM, Roach B (2018) Environmental and natural resource economics a contemporary approach. Routledge, London

Haynes RJ (2008) Soil organic matter quality and the size and activity of the microbial biomass: their significance to the quality of agricultural soils. Soil mineral microbe-organic interactions. Springer, Berlin, pp 201-231

Heilmann B, Lebuhn M, Beese F (1995) Methods for the investigation of metabolic activities and shifts in the microbial community in a soil treated with a fungicide. Biol Fertil Soils 19:186-192. https ://doi.org/10.1007/bf00336157

Hu J, Lin X, Wang J et al (2011) Microbial functional diversity, metabolic quotient, and invertase activity of a sandy loam soil as affected by long-term application of organic amendment and mineral fertilizer. J Soils Sediments 11:271-280. https://doi. org/10.1007/s11368-010-0308-1

ICAP 7000 (1994) EPA method 200.7, Revision 4.4: determination of metals and trace elements in water and wastes by inductively coupled plasma-atomic emission spectrometry. Appl NotesiCAP Revision 4: revision 4.4. https://doi.org/10.1017/cbo97 81107415324.004

Instytut Agrofizyki w Lublinie W, Stepniewska Z, Glinski J et al (2000) Dehydrogenase activity of some Hungarian soils as related to their water and aeration status. Int Agrophysics 14:341-354

Joardar JC, Rahman MM (2018) Poultry feather waste management and effects on plant growth. Int J Recycl Org Waste Agric. https ://doi.org/10.1007/s40093-018-0204-z

Kashyap SKR, Khokhar KK (2017) Long-term effects of organic manures and fertilizers on soil enzymes activity. Int J Chem Stud 5:449-452

Komatsuzaki M, Ohta H (2007) Soil management practices for sustainable agro-ecosystems. Sustain Sci 2:103-120. https://doi. org/10.1007/s11625-006-0014-5

Kumar Choudhary A, Suri VK (2014) Communications in soil science and plant analysis integrated nutrient-management technology for direct-seeded upland rice (Oryza sativa) in Northwestern Himalayas. Commun Soil Sci Plant Anal 45(6):777

Kuzyakov Y, Friedel JK, Stahr K (2000) Review of mechanisms and quantification of priming effects. Soil Biol Biochem 32:14851498. https://doi.org/10.1016/s0038-0717(00)00084-5

Liang Y, Yang Y, Yang C et al (2003) Soil enzymatic activity and growth of rice and barley as influenced by organic manure in an anthropogenic soil. Geoderma 115:149-160. https://doi. org/10.1016/s0016-7061(03)00084-3

Liu Z, Rong Q, Zhou W, Liang G (2017) Effects of inorganic and organic amendment on soil chemical properties, enzyme activities, microbial community and soil quality in yellow clayey soil. PLoS One 12:e0172767. https://doi.org/10.1371/journal.pone.0172767

Macci C, Doni S, Peruzzi E et al (2012) Bioremediation of polluted soil through the combined application of plants, earthworms and organic matter. J Environ Monit 14:2710. https://doi.org/10.1039/ c2em30440f

Maithani K, Arunachalam A, Tripathi RS, Pandey HN (1998) Influence of leaf litter quality on $\mathrm{N}$ mineralization in soils of subtropical humid forest regrowths. Biol Fertil Soils 27:44-50. https://doi. org/10.1007/s003740050398

Martens DA, Johanson JB, Frankenberger WT Jr (1992) Production and persistence of soil enzyme with repeated addition of organic residues. Soil Sci 153:53-61

Moscatelli MC, Lagomarsino A, Marinari S et al (2005) Soil microbial indices as bioindicators of environmental changes in a poplar plantation. Ecol Indic 5:171-179. https://doi.org/10.1016/j.ecoli nd.2005.03.002 
Murphy RP, Montes-Molina JA, Govaerts B et al (2016) Crop residue retention enhances soil properties and nitrogen cycling in smallholder maize systems of Chiapas, Mexico. Appl Soil Ecol. https ://doi.org/10.1016/j.apsoil.2016.03.014

Nannipieri P, Giagnoni L, Landi L, Renella G (2011) Role of phosphatase enzymes in soil. Phosphorous in action, 26th edn. Springer, Berlin, pp 215-243

Odum EP (2014) The strategy of Ecosystem development. The ecological design and planning reader. Island Press, Washington, pp 203-216

Olsen SR, Cole CV, Watanabe FS, Dean La (1954) Estimation of available phosphorus in soils by extraction with sodium bicarbonate. USDA Circ 939:1-19. https://doi.org/10.2307/302397

Pampuro N, Dinuccio E, Balsari P, Cavallo E (2016) Evaluation of two composting strategies for making pig slurry solid fraction suitable for pelletizing. Atmos Pollut Res 7:288-293. https://doi. org/10.1016/j.apr.2015.10.001

Pampuro N, Bertora C, Sacco D et al (2017) Fertilizer value and greenhouse gas emissions from solid fraction pig slurry compost pellets. J Agric Sci 155:1646-1658. https://doi.org/10.1017/S0021 $85961700079 \mathrm{X}$

Partap T (2011) Hill agriculture: challenges and opportunities. Indian J Agric Econ 66:33-52

Paudel B, Radovich TJ, Chan-Halbrendt C et al (2014) ScienceDirect effect of conservation agriculture on maize-based farming system in the mid-hills of Nepal. Procedia Eng 78:327-336. https://doi. org/10.1016/j.proeng.2014.07.074

Putnam AR (1994) Phytotoxicity of plant residues. Manag Agric Residues 16:285-314

Richardson AE (2001) Prospects for using soil microorganisms to improve the acquisition of phosphorus by plants. Funct Plant Biol 28:897. https://doi.org/10.1071/pp01093

Romano E, Brambilla M, Bisaglia C et al (2014) Pelletization of composted swine manure solid fraction with different organic co-formulates: effect of pellet physical properties on rotating spreader distribution patterns. Int J Recycl Org Waste Agric 3:101-111. https://doi.org/10.1007/s40093-014-0070-2

Rousk J, Brookes PC, Bååth E (2010) The microbial PLFA composition as affected by $\mathrm{pH}$ in an arable soil. Soil Biol Biochem 42:516-520. https://doi.org/10.1016/j.soilbio.2009.11.026

Roy S, Arunachalam K, Dutta BK, Arunachalam A (2010) Effect of organic amendments of soil on growth and productivity of three common crops viz. Zea mays, phaseolus vulgaris and abelmoschus esculentus. Appl Soil Ecol 45:78-84. https://doi.org/10.1016/j. apsoil.2010.02.004

Sakurai M, Wasaki J, Tomizawa Y et al (2008) Analysis of bacterial communities on alkaline phosphatase genes in soil supplied with organic matter. Soil Sci Plant Nutr 54:62-71. https://doi.org/10.1 111/j.1747-0765.2007.00210.x

Shukla G, Varma A (2011) Soil enzymology. Springer, Berlin

Silveira MLA, Alleoni LRF, Guimarães LR (2003) Biosolids and heavy metals in soils. Sci Agric 60:793-806. https://doi.org/10.1590/ s0103-90162003000400029

Singh BP, Cowie AL (2011) Soil health and climate change. Springer, Berlin

Singh B, Gilkes RJ (1992) Properties and distribution of iron oxides and their association with minor elements in the soils of south-western Australia. J Soil Sci 43:77-98. https://doi. org/10.1111/j.1365-2389.1992.tb00121.x
Speir T, Ross D (1978) Soil phosphatase and sulphatase. Soil enzymes. Burn RG Academic Press, London, pp 197-250

Srivastava A, Dagbenonbakin GD, Gaiser T (2010) Effect of fertilization on yam (Dioscorea rotundata) biomass production. J Plant Nutr 33:1056-1065. https://doi.org/10.1080/01904161003729766

Stenberg B, Johansson M, Pell M et al (1998) Microbial biomass and activities in soil as affected by frozen and cold storage. Soil Biol Biochem 30:393-402. https://doi.org/10.1016/s0038 -0717(97)00125-9

Subbaiah B, Asija GL (1956) A rapid procedure for the estimation of available nitrogen in soils. Curr Sci 25:259-260

Tabatabai MA, Bremner JM (1969) Use of p-nitrophenyl phosphate for assay of soil phosphatase activity. Soil Biol Biochem 1:301-307. https://doi.org/10.1016/0038-0717(69)90012-1

Tamilselvi SM, Chinnadurai C, Ilamurugu K et al (2015) Effect of long-term nutrient managements on biological and biochemical properties of semi-arid tropical alfisol during maize crop development stages. Ecol Indic 48:76-87. https://doi.org/10.1016/j.ecoli nd.2014.08.001

Toth SJ, Prince AL (1949) Estimation of cation exchange capacity and exchangeable $\mathrm{Ca}, \mathrm{K}$ and $\mathrm{Na}$ contents of soils by flamephotometric techniques. Soil Sci 67:439-445

Tripathi S, Chakraborty A, Chakrabarti K, Bandyopadhyay BK (2007) Enzyme activities and microbial biomass in coastal soils of India. Soil Biol Biochem 39:2840-2848. https://doi.org/10.1016/j.soilb io.2007.05.027

Vance ED, Brookes PC, Jenkinson DS (1987) An extraction method for measuring soil microbial biomass C. Soil Biol Biochem 19:703707. https://doi.org/10.1016/0038-0717(87)90052-6

Walkley AJ, Black IA (1934) Estimation of soil organic carbon by the chromic acid titration method. Soil Sci 37:29-38

Woli A, St Z, Wolińska A, Stępniewska Z (2012) Dehydrogenase activity in the soil environment. Dehydrogenases. https://doi. org/10.5772/48294

Yadav A, Ansari KB, Simha P et al (2016) Vacuum pyrolysed biochar for soil amendment. Resour Technol 2:S177-S185. https://doi. org/10.1016/j.reffit.2016.11.004

Yu H, Si P, Shao W et al (2016) Response of enzyme activities and microbial communities to soil amendment with sugar alcohols. Microbiologyopen 5:604-615. https://doi.org/10.1002/mbo3.355

Zavalloni C, Alberti G, Biasiol S et al (2011) Microbial mineralization of biochar and wheat straw mixture in soil: a short-term study. Appl Soil Ecol 50:45-51. https://doi.org/10.1016/j.apsoi 1.2011.07.012

Zhang Q, Liang G, Zhou W et al (2016) Fatty-acid profiles and enzyme activities in soil particle-size fractions under long-term fertilization. Soil Sci Soc Am J 80:97-111. https://doi.org/10.2136/sssaj 2015.07.0255

Zhen Z, Liu H, Wang N et al (2014) Effects of manure compost application on soil microbial community diversity and soil microenvironments in a temperate cropland in China. PLoS One. https:// doi.org/10.1371/journal.pone.0108555

Publisher's Note Springer Nature remains neutral with regard to jurisdictional claims in published maps and institutional affiliations. 